\title{
The Influence of Public Relations on Consumer Purchasing Decisions: Study on CV. Ranjang 69 Garut
}

\author{
Hari Mulia \\ Department of English, STIE Yasa Anggana, Garut, Indonesia \\ hari.mulia@yahoo.co.id \\ ${ }^{*}$ Corresponding Author \\ Whatsapp Number: [085224400080]
}

How to Cite : Mulia, H. (2019). The Influence of Public Relations on Consumer Purchasing Decisions: Study on CV. Ranjang 69 Garut. International Journal for Educational and Vocational Studies, 1 (3), 193-200.

\section{ARTICLE HISTORY}

Received: 4 May 2019

Revised: 12 June 2019

Accepted: 22 July 2019

KEYWORDS

Public Relations;

Purchasing Decisions

\section{ABSTRACT}

This study is motivated by consumer purchasing decisions on CV. Ranjang 69 Garut which has decreased in the past few years based on sales data from the marketing department and found several problems that occur in the field. This can be caused by several things, namely the desire of different consumers in choosing the ramen noodle shop, consumer tastes that are constantly changing along with the increasing number of similar products, unpleasant experiences of consumers who have consumed them, store locations that are less visible to consumers, consumers are less sure to buy the product, the influence of information from consumers who have bought is negative, consumers feel less satisfied with the product so they do not make repeat purchases. Based on the analysis, the results obtained that the research instrument used in this study was declared valid because it has a value of $>0.30$ and is reliable because the research instruments from public relations have a value of $>0.553$ and the research instruments from consumer purchasing decisions have a value $>0.444$. From the results of the correlation coefficient test obtained information that public relations has a moderate influence on consumer purchasing decisions with a correlation value of 0.542 and the magnitude of the test coefficient of determination to determine the contribution of public relations to consumer purchasing decisions by $26.5 \%$ and the remaining $73.5 \%$. Respondents about public relations on CV. Beds 69 Garut is included in the agreed category, as well as the responses of respondents about consumer purchasing decisions on CV. Ranjang 69 Garut is included in the agreed category as well.

This is an open access article under the CC-BY-SA license.

\section{INTRODUCTION}

The use of technology nowadays needs to be important. It can replace conventional methods by paper based assessment with the use of technology is needed by everyone. Earlier research has shown a range of motivations for implementing CAA in a course, and often a combination of factors result in CAA being used (Bull \& McKenna, 2001). Nolan and Martin (1994) stated that learning in new environments such as using the internet in schools has made many influences for the students. The students will be more adept at making judgments and thinking more critically. Nonetheless, socio-economic conditions among students must take approximately during the exposure of computer and internet technology to be provided (Bier et. Al, 1996). Teachers will find it easy to identify students and schools will be more well-known among the public because of the assumption that people prefer schools with highly advanced technology. Although the costs incurred by schools or educators are not cheap because current technology is very expensive. The curriculum is holistic where knowledge, skills and values (values) are integrated with information needs in competency-based curriculum.

Over the past decade there has been a large increase in the use of computer-based assessment (Stephens \& Mascia, 1997). Computer based assessment is a process of systematically gathering evidence and making decisions about a person's behavior towards established competency standards. Assessments should be interconnected between skills, knowledge and attitudes and useful applications, candidates/examiners must show that they are competent in all tasks, not just partially. Appraisal based on competence is not only about performance, knowledge and understanding are fundamental to performance and the need to be assessed. Assessment in learning is a formal process or effort to gather information related to important variables of learning as material in decision making by teachers to improve the process and student learning outcomes. 
Schools make it easier for teachers and students to use structured and scheduled teaching materials or learning instructions through the internet, so that both can assess each other to what extent the teaching material is learned. Students can learn or review teaching materials at anytime and anywhere if necessary considering the material teaching is stored on the computer. When students need additional information related to the material they are studying, they can access the internet. Both teachers and students can hold discussions through the internet which can be followed by a large number of participants, thus increasing knowledge and insight large. Changing the role of students from usually passive to active.

Based on the above exposure, there is a curiosity to find out and analyze how online examinations were conducted in formal schools and what are the influences of the online exam itself for teachers and students. Today business competition is increasingly felt in the economic climate. This was marked by Indonesia's economic growth in 2017 which reached $5.07 \%$ which created a condition that requires every business person to be more aggressive in expanding his business area. With the competition, various companies try to create the best products so that the products they have can be accepted by the community. The number of products in circulation has resulted in the need for various considerations for the community in making purchasing decisions.

Understanding the wants and needs of consumers is something that should be a concern of marketers, because consumers with the power of bargaining have a big influence on the sustainability of the company, because the company will know and understand how consumers make purchasing decisions for a product. The stages before reaching a purchasing decision from the consumer that the company must pay attention to various things, including the products that are owned must provide benefits, according to the needs and desires of consumers.

The success of the company in influencing consumers in purchasing decisions is strongly supported through efforts to build communication to consumers that is carried out sustainably. Communication in marketing aims to disseminate information, influence, persuade or remind the target market of the company and its products to be willing to accept, buy products offered by the company concerned. The company usually uses promotion mix communication facilities in its marketing activities. One element of the promotion mix is public relations.

Public relations is an activity to create good relations with the public, so that people have a good image of the company. The company must not only deal constructively with customers, suppliers and suppliers, but must deal with a large collection of public interests. Public is any group that has actual and potential interests or influence on a company's ability to achieve its objectives. Public relations helps companies communicate with customers, shareholders, government officials, employees and the community. Marketers not only use public relations to maintain a positive impression about the company but also educate the public about the company's goals and objectives and introduce new products and help support the company's product sales business. Public relations is used to promote products, people, places, ideas, activities, organizations and even the nation. Public relations can have a strong impact on public awareness at a cost that is much cheaper than advertising.

Today the development of the era is progressing and the consumption patterns of society are increasing, making the growth of companies in the business world also increase, especially in the food sector. CV. Ranjang 69 or Ramen Jangar 69 is a company engaged in Japanese culinary specialties with superior products, which are modified ramen with distinctive Sundanese flavors with different levels of spiciness, affordable prices and various menu variants and toppings available to consumers. CV. Ranjang 69 was founded by Rizqi Rakhmanul Hakim on September 9, 2012 in front of the campus of Padjadjaran University (Unpad) Jatinangor. Now CV. Beds 69 has 11 branches spread in Garut, Depok, Tangerang, Karawang, Bekasi, Cimahi. One of the Garut branches from Ranjang 69 has its address at Jl. Cimanuk No. 164, Jayaraga, Tarogong Kidul, Kab. Garut - West Java 44151. In its marketing, CV. Ranjang 69 uses promotional media, one of which is public relations.

The increasingly fierce competition in the food business world created by several companies makes competition increasingly fierce and very competitive. The decline in sales made by CV. Ranjang 69 Garut shows a problem in consumer purchasing decisions, this is caused by: 1) The desire of different consumers in choosing a Ramen noodle shop. 2) Consumer tastes that keep changing along with the increasing number of similar products. 3) An unpleasant experience from consumers who have consumed it. 4) Store locations that are less visible to consumers. 5) Consumers are not sure about buying the product. 6) The influence of information from consumers who have bought is negative. 7) Consumers feel less satisfied with their products so they do not make repeat purchases. 8) Companies do not conduct publications, namely one of the activities or tools in public relations, where the company relies heavily on published material to reach the target market.

Regarding the importance of Public Relations to Consumer Purchase Decisions, this should be considered by CV. Beds 69 Garut, because with the existence of good public relations, the company can increase purchasing decisions made by consumers, according to the theory mentioned by Kotler and Armstrong quoted by Alma (2009: 188), public relations and sales promotion is an advertising activity or tool promotion. Where the task of advertising is to give an invitation to prospective consumers to get to know and buy products. 


\section{METHODS}

Based on the background described, the compiler conducts research with the title "The Influence of Public Relations Against Consumer Purchasing Decisions (Study on CV. Beds 69 Garut)". In this paper the explanatory method is used. According to Singarimbun (2003: 46) the explanation method is if the researcher explains the relationship/influence between variables through hypothesis testing called explanatory researchers (Eksplanatory Research).

\section{Variable Operationalization}

Independent variable or independent variable, which is a variable that affects or becomes the cause of change or emergence of the dependent variable (dependent variable). Dependent variable is a variable that is affected or that becomes a result, because of the existence of independent variables. (sugiyono, 2010: 59) Variables studied are:

Independent variable (X): Public Relations (Y): Purchase Decision

\section{Data analysis technique}

\section{Pearson Correlation Coefficient Analysis}

To find out how much influence the influence of the independent variable (public relations) on the Purchase Decision the researcher uses the analysis technique of the Product Moment Pearson Correlation Coefficient (sugiyono, 2008: 183)

$$
\mathrm{r}_{\mathrm{XY}}=\frac{\sum \mathrm{nXY}-\sum \mathrm{X} \sum \mathrm{Y}}{\sqrt{\left\{\mathrm{n} \sum \mathrm{X}^{2}-\left(\sum \mathrm{X}\right)^{2}\right\}\left\{\mathrm{n} \sum \mathrm{Y}^{2}-\left(\sum \mathrm{Y}\right)^{2}\right\}}}
$$

\section{. Where:}

$r x y=$ Pearson correlation coefficient in question

$\mathrm{x}=$ Independent Variables (public relations)

$y=$ Dependent Free Variables (Purchase Decisions)

$\mathrm{n}=$ Year

To find out which criteria include the results of the analysis, it can be seen in the table below as a guideline to provide an interpretation of the correlation coefficient.

\section{Determination Coefficient Test $\left(R^{2}\right)$}

Testing the coefficient of determination, aims to provide the proportion or percentage of total variation in the non-free variable (Product Quality) which is explained by the independent variable (Product Design) while the formula for calculating the coefficient of determination is as follows: variable gives almost all the information needed to predict the variation of the dependent variable and if $\mathrm{R} 2=0$ shows that the independent variables cannot explain dependent variable.

\section{Hypothesis testing}

According to Sugiyono (2016: 70), the hypothesis is a temporary answer to the formulation of research problems, where the formulation of research problems has been expressed in the form of question sentences.

According to Umar (2007: 104) in the hypothesis test design the testing steps are as follows:

\section{Determine the statistical hypothesis first}

Ho $=$ There is no positive and significant influence between the Public Relations on Consumer Purchase Decisions.

$\mathrm{Ha}=$ There is a positive and significant influence between Public Relations on Consumer Purchase Decisions.

\section{Determine the level of error used}

In the research the error rate used is $\alpha=5 \%$, because the error rate $\alpha=5 \%$ is generally often used in social and economic or non-exact sciences research according to Riduwan and Akdon (2008: 249).

\section{Test the significance of the degrees of freedom or} (degrees of freedom)

$\mathrm{dk}=\mathrm{n}-2$ and use the $\mathrm{t}$ test statistical method so that the price $r$, can be determined by calculating " $t$ " related to that price, namely the formula:

Where :

$\mathrm{r}=$ spearman rank correlation coefficient

$\mathrm{r}^{2}=$ coefficient of determination $\mathrm{n}=$ number of samples

Under the condition :

If thitung $>\mathrm{t}$ table, then $\mathrm{H}_{\mathrm{o}}$ is rejects and $\mathrm{Ha}$ is accepted. If $\mathrm{t}$ count $<\mathrm{t}$ table, then $\mathrm{H}$ is accepted and $\mathrm{Ha}$ is rejected.

\section{RESULTS AND DISCUSSION}

\section{Test the Validity and Reliability of Research Instruments}

In testing the validity of Public Relations instruments, questionnaires were distributed to 68 respondents consisting of 13 statements, where the respondents were consumers of CV. Ranjang 69 Garut which has purchased Ramen products. Then testing each item statement using product moment correlation. Based on the results of the correlation calculation on each item statement (attached), here are the results of the analysis:

$\mathrm{Kd}=\mathrm{R} 2 \times 100 \%$

This determination coefficient ranges from 0 to $1(0 \leq \mathrm{R} 2 \leq$ 1), the higher R2 (close to 1) means that the independent 
Table 1. Guidelines for Interpreting Correlation Coefficients

\begin{tabular}{cc}
\hline Effect Level Coefficient & Interval \\
\hline $0,000-0,199$ & Very low \\
\hline $0,200-0,399$ & Low \\
\hline $0,400-0,599$ & Is being \\
\hline $0,600-0,799$ & Strong \\
\hline $0,800-1,00$ & Very strong \\
\hline & (Source. Sugivono, 2010:184)
\end{tabular}

Based on the table 39 above and adjusted to table 4.40, the Spearman rank correlation coefficient is 0.542 . The correlation coefficient is at an "intermediate" interval because it is located in the interval $0.400-0.599$. So that it can be interpreted that the influence between variables $\mathrm{X}$ (Public Relations) on Y (Consumer Purchase Decision) on CV. Ranjang 69 Garut has a moderate influence, because the correlation calculation only correlates one variable or one promotional tool from several promotional tools so that the effect is not fully maximized.

\section{Determination Coefficient Test}

Testing the coefficient of determination, aims to measure the magnitude of the influence of variable $\mathrm{X}$ (Design to determine the magnitude of the contribution of the Public Relation to Consumer Purchase Decisions on CV. Ranjang 69 Garut test of determination, while the calculation results of the test coefficient of determination as follows:

Table 2. Coefficient of Determination

Model Summary

\begin{tabular}{l|c|r|r|r}
\hline Model & $R$ & R Square & \multicolumn{1}{c|}{$\begin{array}{c}\text { Adjusted R } \\
\text { Square }\end{array}$} & $\begin{array}{l}\text { Std. Error of the } \\
\text { Estimate }\end{array}$ \\
\hline 1 &, $515^{\mathrm{a}}$ &, 265 &, 254 & 6,422 \\
\hline \multicolumn{2}{l}{ a. Predictors: (Constant), Public Relation }
\end{tabular}

(Source: Results of Primary Data Processing with SPSS 20)

Based on the result above calculation, the determination coefficient is 0.265 or $26.5 \%$. From these results, it can be interpreted that the magnitude of the contribution of the influence of the Public Relation to Consumer Purchase Decisions is $26.5 \%$ and the rest is influenced by other factors not examined in this study such as Advertising, Sales Promotion and Personal Sales (Personal Selling), (Kotler and Armstrong in Alma, 2016: 181).

\section{Hypothesis Test (t test)}

To find out whether the hypothesis is accepted or rejected, then a two-party t test is carried out, with the following hypothesis:

Ho $=$ There is no positive and significant influence between Public Relations towards Consumer Purchasing Decisions.

$\mathrm{Ha}=$ There is a positive and significant influence between the Public Relations and Consumer Purchasing Decisions.

The error rate used is $a=0.05 \%$, generally used in research studies of social and economic sciences, with statistical methods as follows:

Table3. T Test Coefficients ${ }^{\mathrm{a}}$

\begin{tabular}{|c|c|c|c|c|c|c|}
\hline & \multirow{3}{*}{ Model } & \multirow{2}{*}{\multicolumn{2}{|c|}{$\begin{array}{c}\text { Unstandardized } \\
\text { Coefficients }\end{array}$}} & \multirow{3}{*}{$\begin{array}{c}\text { Standardized } \\
\text { Coefficients }\end{array}$} & \multirow{3}{*}{$\mathrm{t}$} & \multirow{3}{*}{ Sig. } \\
\hline & & & & & & \\
\hline & & B & Std. Error & & & \\
\hline \multirow[b]{2}{*}{1} & (Constant) & 35,098 & 8,855 & & 3,963 &, 000 \\
\hline & $\begin{array}{l}\text { Public } \\
\text { Relation }\end{array}$ & ,841 & ,173 & ,515 & 4,877 &, 000 \\
\hline
\end{tabular}

a. Dependent Variable: Consumer Purchasing Decisions

Table 8.

(Source: Results of Primary Data Processing with SPSS 20) Under the condition :

If $t_{\text {count }}>\mathrm{t}$ table, or significant value $<0.05$, then Ho is reject and $\mathrm{Ha}$ are accepted. If tcount $<t_{\text {table, }}$ or significant value $<0.05$, then $\mathrm{Ho}$ is accepted and $\mathrm{Ha}$ is rejected.

Based on the above calculations, it can be seen that $t$ count $>t$ table or $4.877>2,000$ and the significant value of the Public Relation variable $=0,000<0,05$, it can be concluded that Ho is rejected and $\mathrm{Ha}$ is accepted. This means that Public Relations has a positive and significant effect on Consumer Purchasing Decisions. So the proposed hypothesis is acceptable. The discussion of the results of the study will analyze the variables X (Public Relations) and Y variables (Consumer Purchasing Decisions) as well as the relationship to the two research variables on the object of research, Next the researcher describes the discussion of the intended research results as follows:

\section{Public Relations}

Public Relation is the process of communication, where activities are always directed at efforts to influence public opinion in order to be able to behave, argue and behave according to the wishes of the communicator. Public Relation Management is the process of planning, implementing and evaluating programs that stimulate consumer purchases and satisfaction through 
communication about reliable information and through impressions that connect the company and its products according to the needs, desires, concerns and interests of consumers. CV. Beds 69 Garut is one company that uses Public Relations in its promotional activities.

To find out the outline of the responses of respondents to the Public Relations conducted by CV. Beds 69 Garut, the authors distributed questionnaires containing statements about Public Relation activities carried out by CV. Ranjang 69 Garut Public Relations activities are in the category of Agree or Good, can be seen from the results of obtaining rating scale Public Relation of 3477 which is located between 3536 points and between points 4420 , it can be seen from the indicators in the good category which includes: Social media is a media to socialize with each other and is done online that allows humans to interact without being limited by space and time. Social media is one of the tools or means of publication in the Public Relation activities used by CV. Ranjang 69 Garut to communicate and interact online for the marketing business.

Based on the results of the research and responses of respondents that in conducting publication activities through social media conducted by CV. Ranjang 69 Garut helps consumers obtain information and get to know Ramen products. This is in line with the opinion of Kotler and Keller (2016: 642), social media as a tool or method carried out by consumers to share information in the form of text, images, audio, and video to other people and companies or vice versa.

In addition to brands or brands, other media identities are logo. A logo is an image or just a sketch with a certain meaning and represents a meaning of a company, region, organization, product, country, institution and other things that require something short and easy to remember in lieu of its real name. CV. Ranjang 69 Garut has a logo that represents its business identity, because it designs a logo that is quality, unique, attractive and easy to remember to attract new consumers. Based on the results of the research and responses of the respondents that the logo from Ranjang 69 is always easy to remember, the logo that has been chosen has an influence on consumer confidence in making a purchase. This is in accordance with the opinion of Rustan (2009: 13), a logo is a symbol or character used to convey a word, which describes the business field of a business company or organization. A logo in the form of an image used to promote a product or service from a company.

\section{Consumer Purchasing Decisions}

CV. Ranjang 69 Garut always tries to understand and fulfill what consumers need and want. This is because the process of making consumer purchasing decisions begins with the need to try to be fulfilled. To find out the outline of the responses of respondents to Consumer Purchase Decisions made by CV. Beds 69 Garut, the author distributes a questionnaire containing a statement about
Consumer Purchase Decisions made by CV. Beds 69 Garut and Consumer Purchase Decisions are in the Agree or Good category, it can be seen from the results of the rating scale Consumer Purchase Decision of 5317 which is located between points 4080 and point 5440, it can be seen from the indicators in the good category which includes.

The buying procedure is a way to get something through exchange (payment) with money. Based on the results of the research and responses of respondents, respondents were interested in buying Ramen products because the purchase procedure in Garut Beds 69 was so easy that it could increase consumer interest in buying Ramen products in Garut Beds 69, this was because the purchase procedure was one of the things assessed by consumers in making purchases. This is in line with the opinion of Kotler and Armstrong (2008: 184). In the alternative evaluation phase consumers evaluate products to buy, consumers arrange brands in alternative sets of basic marketer concepts in evaluating consumer alternatives, namely purchasing procedures, product attributes, product benefits, product characteristics, importance value and level of preference.

In addition to purchasing procedures, alternative assessments made by consumers in making purchases are product packaging. Product packaging is a form of activity that involves design and products, so that this package can be protected so that the products inside can be protected. Packaging can be used as a communication tool because it brings news or notes about the product. CV. Ranjang 69 Garut has designed as best as possible in terms of the determination of product packaging used, such as shapes, packaging materials, colors, packaging designs and others. Based on the results of the research and responses of the respondents interested in buying Ramen products because the products are packed attractively. Thus, attractive packaging will accelerate the smooth sale of goods, the level of sales and consumer interest in a product.

This is in accordance with Alma's opinion (2016: 160), consumers always have certain considerations in buying goods, and the first attraction is focused on the form, beauty or performance of the package or package (package). Packaging can affect consumers, which are inclusive, emotional, which are not planned in advance. Then the assessment carried out by consumers in making a purchase is seen from the benefits of the product. Consumers not only buy products to satisfy needs, but also aim to satisfy wants. Therefore CV. Ranjang 69 Garut pay careful attention to its product policies, one of which is paying attention to the benefits of its products so that customers do not run into other company's products. Based on the results of research and responses of respondents that Ramen products from CV. Beds 69 Garut provides benefits to consumers. If consumers know and feel the benefits of a product, it will increase consumer confidence in making purchases. This is in accordance with the theory put forward by Alma (2016: 140), if consumers need a product, then imagined first is the 
benefit of the product, then consider other factors beyond benefits. These factors make consumers make decisions to buy or not.

\section{Effect of Public Relation on Consumer Purchasing Decisions on CV. Ranjang 69 Garut}

Public Relations involves various programs designed to promote or introduce products, especially Ramen products from CV. Ranjang 69 Garut to the community and can protect the company's image. CV. Ranjang 69 is a company engaged in Japanese cuisine with its superior product, Ramen. The ramen products offered are different from ramen in general, because the ramen sold is a modification of Japanese ramen into spicy Sundanese ramen with different levels of spiciness at an affordable price. Respondents about the implementation of Public Relations at CV. Beds 69 Garut included in the agree or good category. On the basis of respondents' answers in the questionnaire regarding Ramen products, the number of scores obtained was 3477 , so the respondents included in the agreed category because it was located between 3536 points and between 4420 points.

This indicates that respondents agreed to Public Relation activities on RamenCV products. Beds 69 Garut. While the respondents' responses to the questionnaire regarding Consumer Purchase Decisions, the number of scores obtained was 5317, so the respondents included in the agreed category because it is located between 4080 and 5440 points. This shows that respondents agreed to Consumer Purchase Decisions for Ramen products on CV. Beds 69 Garut. To find out the reliability of the X (Public Relations) variable, it is known that the Cronbach's Alpha value is 0.708 . then compared with the value of $r$ crisis at a significance of 0.05. From table r (Product Moment) with the number of data $n=13$ the value is $=0.553$ or smaller than the value of Cronbach's Alpha or 0.708> 0.553. Thus, all Public Relation instruments that have been compiled meet the requirements of validity and reliability, then the Public Relations instrument can be used to measure in order to collect data. To find out the reliability of the $\mathrm{Y}$ variable (Consumer Purchase Decision), it is known that the value of Cronbach's Alphasebsar is 0.877 then compared to the value of the $r$ crisis at a significance of 0.05 . From table $r$ (Product Moment) with the number of data $n=20$ the value is $=0.444$ or smaller than the value of Cronbach's Alpha or $0.877>0.444$.

Thus, all Consumer Purchase Decision instruments that have been compiled meet the requirements of validity and reliability, then the Consumer Purchase Decision instrument can be used to measure in order to collect data. To determine the effect of Public Relations on Consumer Purchase Decisions, Rank Spearman correlation coefficient was obtained at 0.542 . The correlation coefficient is at an "intermediate" interval because it is located at intervals of 0.400-0.599. So that it can be interpreted that the influence between variables X (Public Relations) on Y (Consumer Purchase Decision) on CV. Ranjang 69 Garut has a moderate influence. To determine the contribution of the Public Relation to Consumer Purchase Decisions, the determination coefficient was obtained at 26.5\%. From these results it can be interpreted that the magnitude of the contribution of the Public Relation to Consumer Purchase Decisions is $26.5 \%$ and the rest $(73.5 \%)$ is influenced by other factors not examined in this study such as Advertising, Sales Promotion (Sales Promotion ) and Personal Selling, (Kotler and Armstrong in Alma, 2016: 181). To test the hypothesis obtained $t$ count $>t$ table or 4.877

$>2,000$ and a significant value of 0,000 is smaller than the level of significance that is set at 0.05 or $0,000<0.05$, it can be concluded Ho is rejected and Ha is accepted. This means that Public Relations has a positive and significant effect on Consumer Purchasing Decisions. So the proposed hypothesis is acceptable.

\section{CONCLUSION}

After conducting research and discussion conducted by the author regarding the Effect of Public Relations on Consumer Purchase Decisions on CV. Beds 69 Garut, the authors conclude as follows:

1. Implementation of Public Relations conducted by CV. Beds 69 Garut is good. This is based on the responses of respondents who generally agree to various indicators of public relations, such as social media, brands and logos have received positive responses from consumers CV. Beds 69 Garut. This shows that consumers CV. Ranjang 69 Garut has a good view and feels very satisfied with the public relations that has been done at CV. Beds 69 Garut.

2. Consumer Purchasing Decisions on CV. Beds 69 Garut on Ramen products are good, seen from the responses of respondents who have felt the benefits of Ramen products, besides that consumers also agree with the attractive packaging of these Ramen products and consumers judge that the buying procedure on CV. Beds 69 Garut is quite easy.

3. Based on the data analysis using a simple correlation technique where the formula used is the rank spearman formula, the results show that the influence of public relations on consumer purchasing decisions is 0.542 which means that the effect is moderate because it is located between $0.400-0.599$.

From the test results of the coefficient of determination it can be concluded that the implementation of Public Relations in contributing to Consumer Purchasing Decisions is $26.5 \%$ and the remaining $73.5 \%$ is influenced by other factors not examined in this study such as Advertising, Promotion Sales (Sales Promotion) and Individual Selling (Personal Selling) (Kotler and Armstrong in Alma, 2016: 181). Then from the results of the hypothesis also obtained $t$ count $>t$ table or $4.877>2,000$ and a significant value of 0,000 smaller than the specified level of significance of 0.05 or $0,000<0.05$, it can be concluded that the hypothesis can 
be accepted or influential Public Relation positive and significant for Consumer Purchasing Decisions.

\section{REFERENCES}

Alma, Buchari. (2009). Management of Marketing and Marketing Services. Bandung: Alfabeta

Alma, Buchari. (2016). Management of Marketing and Marketing Services. Bandung: Alfabeta.

Ardana, I Komang. (2012). Human Resource Management. Jakarta: Salemba Empat.

Arikunto, Suharsimi. (2010). Research Procedure A Practice Approach. Jakarta: Rineka Cipta.

Budiasih, Yanti. (2013). Descriptive Statistics for Economics and Business. Tangerang: Explore Nusa.

Darmawan, Deni. 2016. Quantitative Research Methods. Bandung: PT Remaja Rosdakarya.

Hasan, Iqbal. 2002. Main Material of Research Methodology and its Application, First Edition. Jakarta: Index.

. 2009. Statistical Research Data Analysis. Jakarta: Bumi Aksara.

Hasan, Iqbal. (2009). Statistical Research Data Analysis. Jakarta: Bumi Aksara.

Indrawan, Rully and Poppy Yaniawati. (2014). Research Methodology. Bandung: Refika Aditama

Jefkins, Frank. (2003). Public Relations. Jakarta: Erlangga.

Kotler, Philip and Gary Armstrong. (2004). Basics of Marketing, Ninth Edition Volume 2. Jakarta: PT Index.

Kotler, Philip and Gary Armstrong.(2008). Principles of Marketing, Issue 13 Volume 1. Jakarta: Erlangga.

Kotler, Philip and Gary Armstrong. (2009). Principles of Marketing, Volume 12 Edition 2. Jakarta: Erlangga. Kotler, Philip and Gary Armstrong. (2012). Principles of Marketing, Issue 13. Jakarta: PT Index.

Kotler, Philip and Kevin Lane Keller. 2009. Marketing Management, Issue 13 Volume 2. Jakarta: Erlangga.

Kuncoro, Mudrajad. (2013). Research Methods for Business \& Economics. Jakarta: Erlangga.

Sales Report for 2015-2017. Garut: CV. Bed 69

Lemeshow, Stanley. (1997). Large Samples in Health Research. Yogyakarta: Gadjah Mada University Press.

Lestari, Suci Apriani. (2013). Effects of Public Relation and Sales Promotion on Purchase Decisions. Garut: STIE Yasa Anggana.

Mangkunegara, Anwar Prabu. (2012). Consumer Behavior. Bandung: PT Refika Aditama.

Morissan. 2008. Public Relations Management, Strategy to Become Professional Public Relations. Jakarta: Kencana Prenada Media Group.
Phillipson, Ian. (2008). Public Relations. Jogjakarta: Image Press

Riduwan. (2008). Basics of Statistics. Bandung: Alfabeta

Ruslan, Rosady. (2000). Tips and Strategies, Public Relations Campaign. Jakarta: Rajagrafindo Persada. Ruslan, Rosady. (2005). Public Relation Management \& Media Communication: Concepts and Applications. Jakarta: Rajagrafindo Persada.

Rosady (2008). Tips and Strategies, Public Relations Campaign. Jakarta: Rajagrafindo Persada.

Rosady. (2010). Public Relation Management \& Communication Media: Concepts and Applications. Jakarta: Rajagrafindo Persada.

Rustan, Surianto. (2009). Designing a Logo. Jakarta: PT. Gramedia.

Saladin, Djaslim. (2003). Digest of Marketing and the Elements of Marketing, Third Printing. Bandung: Linda Karya.

Schiffman, Leon and Leslie Lazar Kanuk. (2008). Seventh Edition Consumer Behavior. Jakarta: PT Index.

Setiyaningrum, Ari. et al. (2015). Principles of Marketing. Yogyakarta: Andi offset.

Sugiyono. (2008). Statistics for Research. Bandung: Alfabeta.

Sugiyono. (2010). Business Research Methods. Bandung: Alfabeta.

Sugiyono. (2014). Administrative Research Methods. Bandung: Alfabeta.

Sugiyono. (2016). Administration Research Methods. Bandung: Alfabeta.

Sunyoto, Danang. (2015). Consumer and Marketing Behavior. Yogyakarta: CAPS.

Suryani, Tatik. (2008). Consumer Behavior, Implications for Marketing Strategy. Yogyakarta: Graha Ilmu

Swastha, Basu. (2007). Marketing principles. Yogyakarta: Liberty Offset.

Swastha, Basu and T. Hani Handoko. (2014). Marketing Management (Consumer Behavior Analysis, First Edition). Yogyakarta: BPFE.

Tjiptono, Fandy and Anastasia Diana. (2016). Marketing Essentials and Applications. Yogyakarta: CV Andi Offset.

Tjiptono, Fandy and Gregorius Chandra. (2012). Strategic Marketing 2. Edition of Yogyakarta: Andi Offset.

Umar, Hussein. (2007). Research Methods for Thesis and Business Thesis. Jakarta: PT. Raja Grafindo Persada.

Yulianti, Lina. (2012). Effect of Services and Facilities on Consumer Purchasing Decisions. Solute: STIE Yasa Anggana.

http://www.gurupendidikan.co.id/pengertian-public-relati on-fungsi-dan-tujuan/29-11-2017/19.15wib. 
http://www.statistikian.com/2012/08/menghitung-besar-s ampel-peneliti.html/amp/29-11-2017/20.00wib.

https://angganurrahmanrockets.wordpress.com/2013/11/1 7/purchase-and-faktor-faktor- decisions that affect 04-01-2018/11.35wib. 